\title{
ゼラチンタイプ食品を用いた長期臥床患者に対する 摂食・嚥下機能訓練について
}

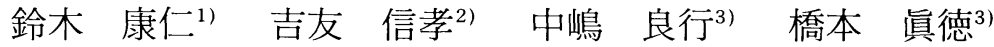

Key words : ゼラチンタイプ食品，摂食・與萩下機能訓練

（日老医誌 $1997 ； 34 ： 759-760 ）$

\section{緒言}

社会の高龄化を迎えて，脳血管障害後遺症や老年痴 呆等の疾患により, 寝たきり状態の患者が急増し1)，そ のため経口攝取が困難な患者も増加している. 従来, そのような患者は経静脈, あるいは経腸法による栄養 管理を余儀なくされ,その結果, ADL の拡大及び QOL の向上に制約を受けているのが実情である。今回我々 は，独自に開発したゼラチンタイプ食品（ムース食） の長期臥床患者の摂食・嶼下機能に対する有用性につ いて検討した。

\section{対 象}

対象は 6 力月以上の長期臥床状態にあり, 経口摂取 が不可能なため経静脈, あるいは経腸栄養法にて管理 され, 症状がほぼ固定したと考えられる本院入院中の 患者84名 (年齢は60 101歳まで, 平均83.2歳) で, そ の内訳は脳梗塞44名, 脳出血11名, くも膜下出血 1 名, パーキンソン病 3 名, 水頭症 1 名, 老年痴呆 24 名であっ た。な抢今回の試みに関しては, 患者本人からの同意 取得を原則としたが，困難な場合は法定代理人等の本 人に代わって同意を成し得るものから同意を得ること を条件とした。

\section{方 法}

ムース食は高栄養流動食である MA-7®（クリニコ）

Usefullness of Gelatin-type Food in Long-term Bedridden Patients Who Have Difficulty in Swallowing Ordinary Foods-in Relation to Swallowing Training -

1) Y. Suzuki：尽誠病院栄養部

2) N. Yoshitomo:同 歯科

3) Y. Nakajima, M. Ilashimoto:同 内科

受付
を主材料とし，ゼラチンパウダーを混ぜ，さらに生ク リーム，粉あめ等を加えてスポンジ状に仕上げられた 1 個あたり 120～140kcal を有する食品である.また患 者の搘好を配慮して，ブルーベリー，バナナ，オレン ジ, 小豆, ニンジン, イチゴ, ココア, 抹茶風味の 8 種類用いた。まずムースの性状を検討するため, 市販 の寒天ゼリーを対照に用い,レオメーター (NRM-2010 $\mathrm{Jcw}$ 型, 不動工業)でテクスチャー測定 ${ }^{2)}$ 及び口腔内温 度に合わせた融解試験を実施した，攝食・曣下機能訓 練は藤島の方法 ${ }^{3} に$ 従った。即ち, 口周辺のマッサー ジ, 口腔清拭, 冷たいスプーン等を唇や舌に触れさせ る基礎訓練から開始し，それを繰り返し，開口及び下 顎の上下運動，唇の閉鎖等が可能になった時点でムー ス食を口腔内に投与し, 咀嚼訓練, さらに嚥下訓練へ と発展させた。

\section{結＼cjkstart果}

レオメーターを用いたテクスチャー測定では，ムー スは硬さ, ガム性, 咀嚼性に於いて寒天ゼリーの $1 / 10$ 以下の值を，また凝集性，もろさではそれぞれ $2 / 3 ， 1 /$ 70值を示し, 食物を実際に咀嚼し, 飲み込む状態にす るまでに非常に少ないエネルギーで斉むことが確認さ れた。次にムース食と寒天ゼリーを口腔内温度に合わ せ, $36^{\circ} \mathrm{C}, 10$ 分間保温状態に静置させる融解試験では, ムースは原形を留めながら一部泡状に融けたが, 寒天 ゼリーはまったく変化を認めなかった。ムースを用い た曣下機能訓練の結果，患者84名のうち，少しでも経 口摂取が可能となったのは72名（85.7\%）であった。 この72名の患者のうち15名（17.9\%）は完全に普通食 に移行でき，27名 (32.1\%) はムース食単独での栄養 管理が可能になった。残りの30名（35.7\%）の患者は 経口捸取が可能とはなったが十分な量を摂取できず, 経静脈あるいは経腸栄養との併用を余儀なくされた (図 1 ). 疾患別の摂食機能訓練の有用性については, 


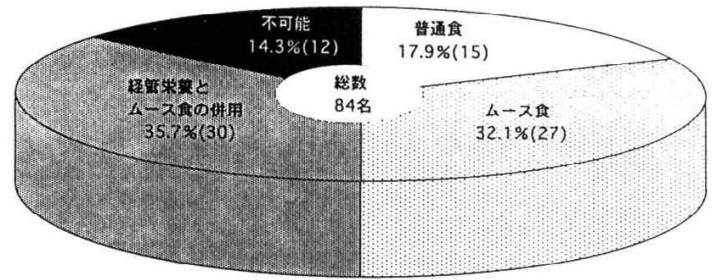

図 1 搨食・曣下機能訓練の有用性

脳梗塞では44名中36名, 脳出血では11名中10名, 老年 痴呆では24名中22名において搨取が可能となった。 まったく効果を認めなかったのは広範囲の脳梗塞や脳 出血, あるいは脳幹部梗塞のような重症の脳血管障害 を有する患者, さらに発症後急速に進行したアルツハ イマー型老年痴呆等であった。また部分的に効果を認 めたのは再発をくり返す脳梗塞でも広範囲に至らない 場合, 及び廃用症候群には至らない程度の高度の痴呆 患者であった．なお今回の機能訓練を通じて誤嚥性肺 炎等の合併症は認めなかった。

\section{考察}

加莑とともに堌加する脳血管障害は少なからず矌下 障害を合併し，またその後遺症により長期間寝たきり の状態を強いられると胃排出機能も低下し4), その結 果, 患者の攝食・臙下障害はますます助長され, QOL の低下及び栄養状態の悪化を招いている．今回我々は このような患者 84 名に対して，ムース食を用いて摄 食・瞬下機能訓練を施行し，広範囲の脳血管障害や痴 呆が急速に進行し, 廃用症候群に至る重症の老年痴呆 等を有しない72名（85.7\%）においては経管栄養との 併用を含めて, 経口掑取が可能となる結果を得た。そ のうち15名は完全に普通食への移行が可能となった。 一般に攝食・㱬下障害をもつ患者にとって食べやすく， 飲み込みやすい食品の条件は, 密度が均一であること， 適当な粘度があってバラバラになりにくいこと，口腔 や咽頭を通過する時に変形しやすいこと，さらにべと つかないことである，従来，嚥下障害を有する患者で は水分や濃厚流動食を経口摂取させると, むせが起こ り，却って誤嬩を来すことが頻回にみられた。この現 象に対して, 液体にデンプン，デキストリン等のとろ み調整食品を混ぜ, 半固形状態にして摂取させること も試みたが誤曣を完全に防止することはできなかっ
た。また一般によく使用されている寒天ゼリーも用い たが，咀嚊後の固形物が咽頭に滞りここれも滑らかに 曣下できず誤曣の原因となった。我々が用いたムース はテクスチャー測定の結果が示すとおり，硬さ，もろ さ, 凝集性, ガム性, 咀嚼性から寒天ゼリーより軟ら かく，変形しやすく，バラバラになりにくかった。ま た融解試験の結果と併せて，ムースは口，舌ざわりが 良く，歯がなくても咀嚼できること，さらに嚥下に適 した形にも変形し, 従来問題とされていた誤嚥の防止 にも好都合と考えられた，栄養管理に関してはムース 1 個あたりのカロリーは120 140kcalであり，それ 故，5〜 7 個を与えることにより，長期臥床高齢者の 1 日のカロリーを十分に補えることが可能である。ま た 8 種類の中から患者の嗜好に合ったムースを選択し て与えることにより，開口がよりスムーズになり，摄 取量も増え，長期投与も可能となった。最近，高跲者 の特街の一つとして, 低蛋白栄養状態, 即ち低アルブ ミン血症が，基礎疾患の有無に関わらず予後や ADL に密接に関係することが示されている5゙。ムース食は 十分な蛋白質を含有することにより，患者の栄養状態 を改善し, ADL の拡大及び QOL の向上に直接結びつ き, 今後, 入院患者のみならず，在宅医療を受けてい る患者にも応用できると考えられた。

本論文の要旨は第39回日本老年医学会学術総会 (東京) て 発表した。

\section{文献}

1）国民衛生の動向. 厚生の指標 (臨時増刊)。第41巻, 第 9 号, 財団法人厚生統計協会, $1994 ; 124$.

2）川端晶子：食品のテクスチャー. 食品物性学(川端 晶子著). 第 2 版，建帛社， $1991 ； \mathrm{p} 97-109$.

3）藤島一郎：高齢者の誤嚥防止と嚥下機能訓練. 日 本醫事新報 $1997 ；$ No. 3800：106-108.

4）井上和彦, 小畠敬太郎，春間 賢，山中秀彦，藤村 二郎, 吉原正治, ほか：腰脳血管障害をもつ高齢者 患者における胃排出能の検討一トリプチンの効果 を含めて一。搘医会誌 $1993 ; 30 ： 41-45$.

5) Corti MC, Guralnik JM, Salive ME, Sorkin DJ : Serum albumin level and physical disability as predictors of mortality in older persons. JAMA $1994 ; 272: 1036-1042$. 